\title{
INFLUENZA VIRUS ISOLATIONS AND SEROLOGICAL STUDIES MADE IN BOSTON DURING THE WINTER OF 1943-1944
}

\author{
By MAXWELL FINLAND, MILDRED W. BARNES, AND BERNARDO A. SAMPER \\ (From the Thorndike Memorial Laboratory, Second and Fourth Medical Services (Harvard), Boston \\ City Hospital, and the Department of Medicine, Harvard Medical School, Boston)
}

(Received for publication August 12, 1944)

Late in March, 1943, a patient was admitted to another hospital in this city and died within a few hours. Autopsy revealed a diffuse hemorrhagic bronchopneumonia and a hemolytic Staphylococcus aureus was obtained in pure culture from the pulmonary lesion. A filtered suspension of this lung was used for virus isolation studies in this laboratory. By serial intranasal passage through mice and by intra-allantoic inoculation in chick embryos, it was possible to isolate a virus which was identified as influenza A (1). Two weeks later, a second case was observed which early in its course suggested that of a severe primary atypical pneumonia. The patient died after an illness of 6 days, toward the end of which she exhibited signs and symptoms consistent with an acute myocarditis and the latter was found at autopsy. No significant bacterial pathogen was found in cultures of the lungs of this patient but mouse and chick embryo inoculations of lung suspensions yielded influenza $A$ virus (2).

As far as could be ascertained, influenza-like infections were not particularly prevalent at this time although mild cases may have occurred and escaped recognition. The experience in these cases, however, suggested that influenza A was occurring in sporadic cases. The last known outbreak of influenza $A$ in which a large number of cases were recognized in Boston occurred as part of the more widespread epidemic of this disease in the fall and winter of 1940-41 $(3,4)$. It was anticipated, however, that another outbreak of influenza might occur during the following season but its nature and extent could not be predicted.

Because of limitations of personnel and facilities and since it was known that extensive studies were being planned by many workers, both in and apart from the armed forces, only limited studies were outlined which would be more suited to the type of material available in a municipal hospital. One of the chief objectives of the projected study was to determine how readily virus could be isolated and identified by the available methods from typical acute cases of epidemic influenza and from the lungs of fatal cases. Particular interest was also centered about the possible predisposing rôle of influenza virus infections in the severe cases of bacterial pneumonia which occur during and shortly after an epidemic of influenza.

The anticipated epidemic did materialize in this country (5) and in Great Britain (6) and possibly in many other countries. Most of the cases in Boston occurred during the first 2 weeks of December 1943. The studies made during the height of this epidemic and for several weeks after it had subsided yielded results that are of some interest and they are reported in this paper.

\section{PATIENTS, MATERIALS, AND METHODS}

Patients. The 4 epidemic cases chosen for isolation of virus from throat washings were admitted to the Boston City Hospital between December 3 and 14. They were considered clinically to be characteristic cases and were selected because they were still acutely ill, with a fever of $102^{\circ} \mathrm{F}$. or higher, and had had symptoms for 2 days or less at the time when the throat washings were obtained. Influenza virus was also isolated from the lung in a fifth case in which death occurred on December 13, 3 hours after admission to the Evans Memorial Hospital.'

Among the cases which are being classified as postepidemic, the first to be studied from which a virus was isolated, was admitted to the Boston City Hospital on January 31, 1944, and died a few hours later of a diffuse bronchopneumonia. Viruses were also isolated from 6 other clinical cases and in 1 other fatal case, all admitted between February 8 and March 12 .

Cases chosen for serological studies included: (1) The clinical cases from which virus isolations were accomplished. (2) Similar patients who were admitted during the height of the epidemic and who were ill more than

1 Materials obtained through the kindness of Drs. Chester S. Keefer and John J. Curry. 
3 days or were already afebrile at the time when they were first seen, so that virus isolations were not attempted. (3) Patients with severe bacterial pneumonia occurring during the height of the epidemic and in the following few weeks. The majority of them were on the medical wards in the middle of January; most of them had extensive pulmonary lesions and many responded poorly to chemotherapy. Each of them gave a history of clinical influenza sometime after the middle of November. (4) A group of patients who were on the wards at the same time for various conditions other than acute respiratory infections but who had had symptoms of an influenza-like infection after the middle of November. (5) Cases similar to the latter whose earlier symptoms were interpreted as those of common cold and not influenza. Most of them had had predominantly coryza without fever or constitutional symptoms. (6) Similar patients and some hospital staff members who had no symptoms either of a common cold or of influenza after October 1943. A few cases of pneumonia are included in the last 2 groups, but very few cases of severe pneumonia were encountered at this time in which there was no history of influenza during the epidemic.

Virus isolations. In the early acute cases, the patients were asked to gargle thoroughly 3 times with $30 \mathrm{ml}$. of sterile broth containing 10 per cent horse serum. The washings were cultured and were then divided into 2 parts, 1 of which was passed through a Berkefeld " $V$ " or a mandler filter. These were used for inoculations immediately or were stored in a carbon-dioxide freezing box for later inoculations.

White mice, in groups of 4 to 6 were each inoculated intranasally under light ether anesthesia and passages of 20 per cent pooled lung suspensions were done at 3- to 5-day intervals. Only the shorter intervals were used in the latter part of the study. After pulmonary lesions began to appear, or if the mice died with extensive and characteristic lesions, subsequent passages were made with $1: 10$ to 1:1000 dilutions of the lung suspensions, depending on the extent of the lesions or the time of death. The presence of the virus was recognized by the characteristic lesions. The virus was then identified by neutralization tests in mice with immune rabbit or ferret serums ${ }^{2}$ prepared against the PR8 (7) strain of influenza A and the Lee (8) strain of influenza B. In some instances, this was corroborated by demonstrating resistance to infection with lethal doses of these standard strains in mice which had previously survived sublethal infections with the patient's virus. Further identification of some of the mouse passage viruses was done by inoculating sterile filtered suspensions into chick embryos, as detailed below, and identifying the virus harvested from the allantoic fluid by agglutination of hen's cells and by the specific inhibition of this agglutination with immune rabbit sera (9).

Direct isolations were also made in chick embryos by adapting the methods of Hirst (10 to 12). The unfiltered or filtered washings, or both were inoculated in $0.1 \mathrm{ml}$. amounts into the chorioallantoic sac of 11- to 12-day-old

${ }^{2}$ Serums obtained through the kindness of Dr. Frank L. Horsfall, Jr. chick embryos ( 3 to 6 eggs each) and the allantoic fluid was harvested after 48 hours additional incubation at $37^{\circ} \mathrm{C}$. The presence of influenza virus was indicated by the agglutination of the red cells of the embryo which were permitted to escape from the ruptured vessels before the harvesting. When there was little or no agglutination visible, the fluid was allowed to stand in an ice bath for 1 to 2 hours in order to adsorb the virus on to the red cells. The supernatant fluid after centrifugation was then removed. A small amount of 10 per cent horse serum broth or of the supernate was added to the sedimented red cells from which the virus was then eluted by incubation for $2 \frac{1}{2}$ hours at $37^{\circ} \mathrm{C}$. with frequent shaking. The cells were then removed by centrifugation and the supernatant serum broth or allantoic fluid containing the virus was used for further passages. When there was a large amount of virus as indicated by strong and immediate agglutination of the red cells as the allantoic fluid was removed, suitable dilutions of the virus up to $1: 100,000$ were used for later passages. When the allantoic fluid was contaminated as evidenced by the dark discoloration or hemolysis of the red cells, the adsorption and elution were followed by filtration before further passages were made. The quantity of virus contained in the allantoic fluid was titrated by agglutination of serial dilutions with hen's cells and it was identified by inhibition of this agglutination with typespecific A and B immune sera (13).

Serological tests. These consisted of complement fixation (14) and agglutination-inhibition $(9,13)$ tests. The antigens used consisted of influenza A (PR8) and B (Lee) as well as the patients' homologous viruses each contained in allantoic fluid of chick-embryo passages. Serial samples of acute and convalescent sera were obtained from the patients in Groups 1 and 2 (see above) and individual or multiple samples of serum were obtained from the remaining patients. The titers are expressed as the reciprocal of the greatest initial dilution of serum giving 25 to 50 per cent hemolysis in the complement fixation tests and almost complete inhibition ( 0 to $1+$ agglutination) in the Hirst tests. The complement fixation tests were carried out in the laboratories of the Department of Bacteriology and Immunology of the Harvard Medical School. We are indebted to Dr. John F. Enders for advice and for the use of his facilities and to Mrs. Jeannette Levens and Miss Elizabeth G. Mills for technical assistance.

\section{ISOLATION OV VIRUSES FROM EPIDEMIC CASES}

Attempts were made to isolate and identify a virus from materials obtained during the height of the epidemic in 5 cases, including 1 fatal case. Throat washings were obtained during the first or second day of the disease in the living cases and a suspension of lung was obtained at autopsy from the fatal case and used for intranasal inoculations of white mice and for intra-allantoic inoculation in chick embryos. Each of the 
patients who furnished the throat washings had a fever of $102^{\circ} \mathrm{F}$. or higher at the time and the illness in each case was of more than average severity. In Case 1 and Case 3, the influenza was apparently uncomplicated except for transient acute sinusitis in the former. In both of these cases, the fever subsided and the patient was definitely improved about 24 hours after the material was obtained. The other 3 patients had, or later developed complicating pulmonary infections. A resumé of these 3 cases follows.

Case 2. A 15-year-old colored boy was admitted to the Boston City Hospital in a comatose condition on the morning of December 4. From his mother it was learned that he had been well until the morning of December 2 when he complained of a "head cold" and stayed home from school. He apparently had had severe headache and chilly sensations but no coryza. During that day and the next, he felt increasing weakness and prostration and asked not to be awakened early the following day. On the morning of December 4 , however, his mother found him comatose in bed, breathing rapidly, with bloody frothy material oozing from his mouth and nose and she sent him into the hospital.

The latter findings were still present when the patient reached the ward. His temperature then was $104^{\circ} \mathrm{F}$., pulse 136, and respiration 60 and shallow. There was slight dulness bilaterally and showers of medium and coarse moist râles were heard throughout both lungs. The rest of the physical examination was essentially negative. The leukocyte count was 4650 with 65 per cent polymorphonuclear neutrophiles, 33 per cent lymphocytes, and 1 per cent each of monocytes and basophiles. X-ray of the chest showed both lung fields diffusely infiltrated with small fluffy areas of density.

Much of the material from the nose and throat was removed by suction and the patient was given oxygen therapy soon after entry. He was then given full doses of sulfadiazine starting with 5 grams of its sodium salt, intravenously. This dose was repeated in 12 hours, after which oral dosage of 1 gram every 4 hours was continued for another week. Improvement began within a few hours, and the patient was afebrile and conscious the following day. He remained apathetic for another 2 or 3 days, after which his recovery was steady and complete. The physical signs in the lungs cleared rapidly but there was still some residual infiltration in the bases of the lungs visible by $x$-ray on December 11 .

The nasopharyngeal washings which were collected shortly after entry and contained some of the bloody and frothy exudate were used for virus studies. Culture of this material showed pneumococcus type 18 in moderate numbers.

Case 4. A 24-year-old nurse began to have chilly sensations, malaise, headache, and a general aching feeling on the morning of December 13. At the time of admission to the ward on December 14 , her temperature was $102^{\circ} \mathrm{F}$., pulse 96 , and respirations 24 , and she felt markedly prostrated. Except for a slightly injected throat, examination was essentially negative. Culture of the throat washings obtained for virus study at this time yielded a scant growth of Staphylococcus aureus. The white blood count was 6700 with 84 per cent polymorphonuclear neutrophiles.

After a few hours, the patient's fever subsided and she felt somewhat improved. During the next day, however, the temperature rose steadily to $103.8^{\circ}$ and the pulse to 140 and the patient again became markedly prostrated. A severe cough with presternal and left lower chest pain began at this time and increased gradually in severity. Sputum was scant at first and became increasingly purulent and copious, with occasional admixtures of blood. Signs of diffuse bronchitis and of bronchopneumonia involving chiefly the left lower lobe became evident and the latter was confirmed by $x$-ray.

Chemotherapy with full oral doses of sulfapyrazine was started at the time of the recurrence of the fever and was continued until January 5 . The patient began to improve after 2 days of this therapy although low grade fever, sputum, and signs of a small amount of fluid in the left pleura and of consolidation and possibly abscess formation of the left lower lobe persisted for 2 weeks. After that time, the patient remained somewhat weak for several days, but cough and pain subsided and the lungs cleared both to physical and $x$-ray examinations. Many specimens of sputum each yielded a copious growth of Staphylococcus aureus in almost pure culture, but cultures of the blood all failed to show any growth. ${ }^{3}$

Case A-1. An 18-year-old female office worker was admitted to the Evans Memorial on December 13. Her illness began 2 days previously with the complaint of sore throat and slight dysphagia. On the following day, she had anorexia, nausea, and vomiting and she became drowsy and prostrated. Early on the morning of admission, she developed extremely severe pain across the lower chest, a productive cough, and rapidly increasing delirium. In this state, she was sent to the hospital.

On arrival, her temperature was $106^{\circ} \mathrm{F}$., pulse 175 , respirations 53, and blood pressure 60/40. She appeared critically ill, toxic, markedly cyanotic, irrational, irresponsive, and incontinent of urine and feces. She was dehydrated and had thick ropy inspissated mucopurulent material at the base of her tongue. There was a deep red diffuse injection of the pharynx. In the lungs, there were signs of patchy consolidation of the right lower lobe and this was confirmed by $x$-ray which also showed some fine mottled infiltration of the middle of the left lung field. The white blood count was 1350 with 24 per cent polymorphonuclear neutrophiles, 72 per cent lymphocytes, and 4 per cent monocytes. Sputum and throat cultures showed beta hemolytic streptococcus and Staphylococcus aureus and the latter was also obtained from the blood culture.

The patient failed to respond to treatment with oxygen and parenteral injections of sulfadiazine, glucose solutions, and various stimulants. Consolidation of the lungs spread

3 A chart showing details of the clinical course and therapy in this case is shown elsewhere (15). 
TABLE I

Isolations of viruses from cases of clinical influenza during and after the epidemic period

\begin{tabular}{|c|c|c|c|c|c|c|c|c|}
\hline \multirow{2}{*}{$\begin{array}{c}\text { Case } \\
\text { no. }\end{array}$} & \multirow{2}{*}{$\begin{array}{c}\text { Date of } \\
\text { onset }\end{array}$} & \multicolumn{2}{|c|}{ Virus isolation } & \multicolumn{2}{|c|}{ Unfiltered } & \multicolumn{2}{|c|}{ Filtered } & \multirow{2}{*}{ Type } \\
\hline & & Date & Source & Mouse & Eg8 & Mouse & Egg & \\
\hline \multicolumn{9}{|c|}{ Epidemic strains } \\
\hline $\begin{array}{r}1 \\
2 \\
3 \\
4 \\
\mathrm{~A}-1\end{array}$ & $\begin{array}{l}\text { Dec. } 2 \\
\text { Dec. } 2 \\
\text { Dec. } 5 \\
\text { Dec. } 13 \\
\text { Dec. } 11\end{array}$ & $\begin{array}{l}\text { Dec. } 3 \\
\text { Dec. } 4 \\
\text { Dec. } 7 \\
\text { Dec. } 14 \\
\text { Dec. } 13\end{array}$ & $\begin{array}{l}\text { Throat } \\
\text { Throat } \\
\text { Throat } \\
\text { Throat } \\
\text { Lung }\end{array}$ & $\begin{array}{l} \pm \\
\pm\end{array}$ & $\frac{\bar{t}}{ \pm}$ & $\frac{ \pm}{\frac{ \pm}{0}}$ & $\frac{ \pm}{ \pm}$ & $\begin{array}{l}\mathbf{A} \\
\mathbf{A} \\
\mathbf{A} \\
\text { ?A } \\
\text { ?A }\end{array}$ \\
\hline
\end{tabular}

Post-epidemic strains

\begin{tabular}{|c|c|c|c|c|c|c|c|c|}
\hline $\begin{array}{r}66 \\
67 \\
68 \\
69 \\
70 \\
71 \\
7-2 \\
A-3\end{array}$ & $\begin{array}{l}\text { Feb. } 2 \\
\text { Feb. } 7 \\
\text { Feb. } 26 \\
\text { Mar. } 5 \\
\text { Mar. } 6 \\
\text { Mar. 11 } \\
\text { Jan. } 23 \\
\text { Mar. } 4\end{array}$ & $\begin{array}{l}\text { Feb. } 8 \\
\text { Feb. } 11 \\
\text { Feb. } 29 \\
\text { Mar. } 12 \\
\text { Mar. } 8 \\
\text { Mar. } 12 \\
\text { Feb. } 11 \\
\text { Mar. 11 }\end{array}$ & $\begin{array}{l}\text { Throat } \\
\text { Throat } \\
\text { Throat } \\
\text { Throat } \\
\text { Throat } \\
\text { Throat } \\
\text { Lung } \\
\text { Lung }\end{array}$ & $\stackrel{+}{+}$ & $\begin{array}{l}\bar{t} \\
\pm \\
0 \\
\pm \\
-\end{array}$ & $\begin{array}{l}\bar{z} \\
\bar{t} \\
+\end{array}$ & $\begin{array}{l}+ \\
+ \\
+ \\
\frac{1}{+} \\
+\end{array}$ & $\begin{array}{l}\text { ? } \\
\text { ?A } \\
? \\
\text { ?A } \\
\text { ?A } \\
\text { ?A } \\
\text { A } \\
\text { A }\end{array}$ \\
\hline
\end{tabular}

$+=$ Virus isolated; $0=$ Failure; $-=$ Not attempted.

rapidly and the patient soon developed muscular twitchings and mild convulsions. She died about 3 hours after admission. Autopsy showed diffuse acute hemorrhagic bronchopneumonia. Hemolytic streptococcus and Staphylococcus aureus were obtained from all parts of the lung, but not from the cardiac blood. Some of this lung was used for the virus studies.

The results of the virus isolation studies in these 5 cases are summarized in the upper portion of Table I and the bacteriological findings are summarized in Table II. Viruses were obtained by direct inoculation of unfiltered throat washings into mice in Cases 1, 2, and 4, and into chick embryos in Cases 2 and 4. In the latter, the allantoic fluids harvested from the first eggs were filtered and further passages were carried out with the filtrates. Mouse-lung suspensions were also filtered before further passage when there was bacterial contamination, but this was no more frequent in mice originally receiving unfiltered lung than in mice which received filtered washings.

Similar mouse and egg inoculations were done with filtered throat washings in Cases 1 and 3 and with the filtrate of the lung suspension of Case A-1. Viruses were obtained in each of these attempts with one exception, namely the mouse inoculations of the lung filtrate of Case A-1.

The presence of virus was noted in the allantoic fluid following the primary inoculation in every instance. This was evidenced by the presence of various degrees of agglutination of the chick cells which were allowed to mix with the allantoic fluid by rupturing the blood vessels before the fluid was harvested. In most instances, the virus contained in this allantoic fluid was concentrated by adsorption on to these cells and eluted into a smaller volume of the supernate, or of serum broth, for subsequent passages. This procedure was sometimes followed also in later egg passages. Whenever there was moderate or marked agglutination, however, the eluent was diluted for subsequent passages.

In mice, characteristic lesions were noted in the lungs in the second or third mouse passage

TABLE II

Predominant organisms in cases of influenza

\begin{tabular}{|c|c|c|c|c|c|}
\hline \multicolumn{3}{|c|}{ Epidemic influenza } & \multicolumn{3}{|c|}{ Post-epidemic cases } \\
\hline Case & Throat & Sputum & Case & Throat & Sputum \\
\hline $\begin{array}{r}1 \\
2 \\
3 \\
4 \\
5 \\
7 \\
8 \\
9 \\
13 \\
\mathrm{~A} 1\end{array}$ & $\begin{array}{l}\text { Str. } \alpha ; \text { S. au. } \\
\text { Pn. 18 } \\
\text { Str. } \alpha \\
\text { S. au. } \\
\text { Str. } \beta \\
\text { Str. } \beta \text {; S. au. } \\
\text { Pn. } 7 \\
\text { Str. } \alpha \\
\text { S. au.; Str. } \beta\end{array}$ & $\begin{array}{l}\text { Pn. } 18 \\
\text { S. au. } \\
\text { Str. } \beta \\
\text { Pn. } 7 \\
\text { Pn. 8, Pn. } 20 \\
\text { Str. } \beta \text {; S. au.* }\end{array}$ & $\begin{array}{l}66 \\
67 \\
68 \\
69 \\
70 \\
71 \\
72 \\
74 \\
\text { A2 } \\
\text { A3 }\end{array}$ & $\begin{array}{l}\text { Str. } \alpha \\
\text { Str. } \alpha \\
\text { Str. } \beta \\
\text { Str. } \beta \\
\\
\text { Pn. } 1\end{array}$ & $\begin{array}{l}\text { Pn. 13; Str. } \alpha \\
\text { Pn. 28; Str. } \alpha \\
\text { Pn. } 9 \\
\\
\text { Str. } \alpha \\
\text { Pn. } 9 \\
\text { Str. } \alpha^{*} \\
\text { Pn. } 1^{*}\end{array}$ \\
\hline
\end{tabular}

Str. = Streptococcus; S. au. = Staphylococcus aureus; Pn. = Pneumococcus.

* Same organisms obtained from lungs at autopsy. Blood cultures were sterile in each instance except in Case A1, S. au. was cultured from the blood before death and in Case A3 Pn. 1 was obtained from the blood during life and from cardiac blood taken at autopsy. 
in each instance and deaths began to occur in 3 to $\mathbf{5}$ days in the mice of the third to the fifth passage. The results of both the mouse and egg inoculations were similar with the filtered and with the unfiltered washings. In the mice inoculated with the filtered suspension of lung from Case A-1, lesions were not obtained after 6 passages and further attempts were not made.

The viruses obtained in Cases 1, 2, and 3 from both mice and chick embryos were readily indentified as strains of influenza A similar to PR8. Neutralization tests in mice were carried out with antisera prepared in ferrets and rabbits against the PR8 strain of influenza $A$ and the Lee strain of influenza $B$. The influenza $A$ serum afforded complete protection against 100 to $\mathbf{1 0 0 0}$ lethal doses of these strains while control mice receiving the virus alone and those receiving the anti-B serum together with the same amounts of virus all died with typical lesions. The agglutination of hen's cells by the strains obtained in the allantoic fluid in these cases was inhibited by influenza $A$ antiserum in high titer and only in low titers by influenza B antisera. Rabbit sera were used for the latter titrations.

The egg-passage strains in Cases 4 and A-1 gave only slightly higher titers of agglutination inhibition with anti-A serum than with anti-B serum, and thus differed from the previous strains. The results of neutralization tests in mice with the strains from these 2 cases, however, gave results similar to those obtained in the first 3 cases. Mice were protected from fatal infection with these strains by anti-PR 8 but not by anti-B serum. Further studies of these and other strains are now being carried out in collaboration with Dr. John F. Enders and Miss Elizabeth G. Mills.

\section{SEROLOGICAL STUDIES IN CASES OF EPIDEMIC INFLUENZA}

Blood for serological studies was obtained at the time of the throat washings and at intervals thereafter in Cases 1 to 4 . Serial samples of serum were also collected from 7 other patients, numbers 7 to 13 , who were admitted to the Boston City Hospital with characteristic symptoms of influenza which began between December 1 and 23. They had all been acutely ill and febrile within 1 or 2 days of the time the first blood was obtained, but the onset of influenza had occurred up to $\mathbf{1 5}$ days previously. Cases 5 and 6 are from other hospitals and represent patients who had physical and x-ray signs of atypical pneumonia which followed symptoms of influenza. The latter began on November 14 in Case 5 and on November 24 in Case 6. Except as already mentioned, there were no complications in any of these cases other than the finding of a few scattered crepitant râles which were heard in every case.

The results of the serological tests with the PR8 strain of influenza $A$ in the 13 cases and with the patients' homologous strains in Cases 1 to 4 are given in Table III. In 11 of the patients the initial serum was obtained 6 days or less - after the onset of the influenza. The titers of complement fixing antibodies against PR8 in these initial sera were less than 4 in 4 cases, 8 in 5 cases, and 16 in 12 cases. The first serum in Case 5 was obtained 10 days after the onset and had a titer of 128 and the first serum in Case 13, obtained on the fifteenth day had a titer of $\mathbf{5 1 2}$.

Subsequent sera all showed a significant rise in titer. In Case 12, there was a 4-fold rise between the fifth and eleventh days and a similar rise from the initial high titer occurred between the fifteenth and the eighteenth day in Case 13. In 3 other cases, including Case 5, there was an 8-fold rise in titer and the remaining cases all showed rises which were considerably greater.

The maximum complement fixation titer demonstrated in Case 12 was 32. This was in a serum obtained on the eleventh day which was the last day of observation. In Case 6, the maximum titer was 64 at the time of the last observation made on the thirteenth day. In the remaining cases, the maximum titers ranged from 128 to 2048 and titers of 512 or higher were obtained in 6 cases. Of interest is the demonstration of 4- to 8-fold rises in titer after the end of the third week in Cases 3, 5, and 7. While no special effort was made to determine how long the elevated titers persisted, it is worth noting that titers of 64 to 512 were still present in sera obtained 10 to 12 weeks after the onset of influenza in several cases.

The titers of the agglutination-inhibition tests with PR8 roughly paralleled those of the comple- 
TABLE III

Results of serological tests in cases of clinical influenza observed during the course of the epidemic

\begin{tabular}{|c|c|c|c|c|c|c|}
\hline \multirow{2}{*}{$\begin{array}{l}\text { Case } \\
\text { no. }\end{array}$} & \multirow{2}{*}{$\begin{array}{l}\text { Date of } \\
\text { onset }\end{array}$} & \multirow{2}{*}{$\begin{array}{l}\text { Date of } \\
\text { serum }\end{array}$} & \multirow{2}{*}{$\begin{array}{l}\text { Days } \\
\text { after } \\
\text { onset }\end{array}$} & \multicolumn{2}{|c|}{ Titer vs. PR8 } & \multirow{2}{*}{$\begin{array}{l}\text { Titer of } \\
\text { A.I. vs. } \\
\text { own strain }\end{array}$} \\
\hline & & & & C.F. & A.I. & \\
\hline 1 & Dec. 2 & $\begin{array}{l}\text { Dec. } 3 \\
\text { Dec. } 7 \\
\text { Dec. } 24 \\
\text { Jan. } 31 \\
\text { Feb. } 28\end{array}$ & $\begin{array}{r}1 \\
5 \\
22 \\
60 \\
88\end{array}$ & $\begin{array}{r}16 \\
32 \\
128 \\
64 \\
64\end{array}$ & $\begin{array}{r}16 \\
8 \\
256 \\
128 \\
64\end{array}$ & $\begin{array}{r}8 \\
8 \\
64 \\
128 \\
256\end{array}$ \\
\hline 2 & Dec. 2 & $\begin{array}{ll}\text { Dec. } 5 \\
\text { Dec. } 13\end{array}$ & $\begin{array}{r}3 \\
11\end{array}$ & $\begin{array}{r}<4 \\
256\end{array}$ & $\begin{array}{r}4 \\
256\end{array}$ & $\begin{array}{l}<4 \\
512\end{array}$ \\
\hline 3 & Dec. 5 & $\begin{array}{ll}\text { Dec. } & 7 \\
\text { Dec. } & 31 \\
\text { Jan. } 17 \\
\text { Feb. } 28\end{array}$ & $\begin{array}{r}2 \\
26 \\
43 \\
85\end{array}$ & $\begin{array}{r}<4 \\
128 \\
2048 \\
512\end{array}$ & $\begin{array}{r}4 \\
256 \\
512 \\
256\end{array}$ & $\begin{array}{r}4 \\
128 \\
512 \\
256\end{array}$ \\
\hline 4 & Dec. 13 & $\begin{array}{l}\text { Dec. } 14 \\
\text { Dec. } 20 \\
\text { Dec. } 28 \\
\text { Jan. } 17 \\
\text { Feb. } 28\end{array}$ & $\begin{array}{r}1 \\
7 \\
15 \\
35 \\
77\end{array}$ & $\begin{array}{r}<4 \\
64 \\
1024 \\
1024 \\
512\end{array}$ & $\begin{array}{r}8 \\
256 \\
512 \\
512 \\
256\end{array}$ & $\begin{array}{r}<4 \\
16 \\
\\
256 \\
128\end{array}$ \\
\hline 5 & Nov. 14 & $\begin{array}{l}\text { Nov. } 24 \\
\text { Nov. } 27 \\
\text { Dec. } 2 \\
\text { Dec. } 7 \\
\text { Dec. } 10 \\
\text { Dec. } 20\end{array}$ & $\begin{array}{l}10 \\
13 \\
18 \\
23 \\
26 \\
37\end{array}$ & $\begin{array}{r}128 \\
128 \\
256 \\
256 \\
1024 \\
512\end{array}$ & $\begin{array}{l}512 \\
256\end{array}$ & \\
\hline 6 & Nov. 24 & $\begin{array}{l}\text { Nov. } 30 \\
\text { Dec. } 7\end{array}$ & $\begin{array}{r}6 \\
13\end{array}$ & $\begin{array}{r}8 \\
64\end{array}$ & $\begin{array}{r}8 \\
64\end{array}$ & \\
\hline 7 & Dec. 1 & $\begin{array}{l}\text { Dec. } 7 \\
\text { Dec. } 12 \\
\text { Dec. } 28 \\
\text { Jan. } 17 \\
\text { Feb. } 21\end{array}$ & $\begin{array}{r}6 \\
11 \\
27 \\
47 \\
82\end{array}$ & $\begin{array}{r}8 \\
32 \\
64 \\
128 \\
256\end{array}$ & $\begin{array}{r}8 \\
32 \\
128 \\
128 \\
128\end{array}$ & \\
\hline 8 & Dec. 5 & $\begin{array}{l}\text { Dec. } 6 \\
\text { Dec. } 13 \\
\text { Dec. } 23 \\
\text { Feb. } 1 \\
\text { Mar. } 1\end{array}$ & $\begin{array}{r}1 \\
8 \\
18 \\
58 \\
87\end{array}$ & $\begin{array}{r}8 \\
128 \\
128 \\
64 \\
64\end{array}$ & $\begin{array}{r}8 \\
32 \\
32 \\
128 \\
128\end{array}$ & \\
\hline 9 & Dec. 6 & $\begin{array}{l}\text { Dec. } 9 \\
\text { Jan. } 4\end{array}$ & $\begin{array}{r}3 \\
28\end{array}$ & $\begin{array}{r}8 \\
512\end{array}$ & 256 & \\
\hline 10 & Dec. 12 & $\begin{array}{l}\text { Dec. } 14 \\
\text { Dec. } 23 \\
\text { Feb. } 21\end{array}$ & $\begin{array}{r}2 \\
11 \\
71\end{array}$ & $\begin{array}{l}<4 \\
512 \\
256\end{array}$ & $\begin{array}{r}4 \\
256 \\
32\end{array}$ & \\
\hline 11 & Dec. 15 & $\begin{array}{l}\text { Dec. } 16 \\
\text { Dec. } 30 \\
\text { Jan. } 17 \\
\text { Feb. } 22\end{array}$ & $\begin{array}{r}1 \\
15 \\
33 \\
69\end{array}$ & $\begin{array}{r}16 \\
128 \\
256 \\
256\end{array}$ & $\begin{array}{r}16 \\
256 \\
128 \\
128\end{array}$ & \\
\hline 12 & Dec. 17 & $\begin{array}{l}\text { Dec. } 22 \\
\text { Dec. } 28\end{array}$ & $\begin{array}{r}5 \\
11\end{array}$ & $\begin{array}{r}8 \\
32\end{array}$ & $\begin{array}{r}4 \\
64\end{array}$ & \\
\hline 13 & Dec. 23 & $\begin{array}{ll}\text { Jan. } & 7 \\
\text { Jan. } & 10 \\
\text { Jan. } & 21\end{array}$ & $\begin{array}{l}15 \\
18 \\
29\end{array}$ & $\begin{array}{r}512 \\
2048 \\
512\end{array}$ & $\begin{array}{l}512 \\
512 \\
512\end{array}$ & \\
\hline
\end{tabular}

C.F. = Complement fixation; A.I. = Inhibition of red cell agglutination (Hirst). Dates: Nov. and Dec. 1943; Jan. and Feb. 1944. The patients' own virus strains were isolated on the day the first serum was obtained. ment fixation tests. The titers of the individual sera were either the same or showed a 2 -fold difference with the latter test usually giving the higher titers. Only occasional sera showed a 4-fold difference. In Cases 1 to 4, the Hirst inhibition titers with the homologous strains showed similar marked rises. There were minor differences, however, in the results of tests with the 2 viruses in individual serum samples.

\section{SEROLOGICAL STUDIES IN OTHER GROUPS OF CASES}

In relation to the influenza epidemic of 194041, Pearson et al. (3) obtained sera from patients with bacterial pneumonia, admitted to the Boston City Hospital during and after the height of the epidemic. Serological evidence was obtained from these cases which indicated that a large number of them had had contact with influenza $A$ virus and suggested a possible relation between the 2 diseases. During the height of the present epidemic and for a few weeks thereafter, it was noted that bacterial pneumonias were occurring with more than the expected frequency and the cases appeared to be unusually severe. Similar increases in the incidence of pneumonia and of its severity, as indicated by a higher mortality, were also noted elsewhere (5). It was, therefore, of some interest to study the serum of patients admitted to the hospital for pneumonia after this epidemic in order to obtain evidence of the rôle being played in these cases by the influenza A virus which was obviously the predominant agent during the epidemic.

Almost all of the patients with severe pneumonia observed during the last half of January gave a history of an influenza-like infection during the epidemic. Sera were, therefore, also obtained from another group of patients who did not have pneumonia but gave a history of symptoms of influenza during the epidemic. The results in the latter cases will be presented first.

\section{ANTIBODIES FOR INFLUENZA A OBTAINED AFTER \\ THE EPIDEMIC IN CASES WITHOUT PNEU- \\ MONIA BUT WITH A HISTORY OF INFLUENZA DURING THE EPIDEMIC}

Sera were obtained between January 17 and February 16 from 13 patients who were admitted 
for a variety of conditions other than pneumónia, but had a history of influenza-like symptoms between December 1 and January 10. Single samples were obtained in 10 of the cases and 2 or 3 samples in each of the other 3 cases. The interval between the onset of the influenza and the time the first or only serum was obtained was less than 3 weeks in 3 cases, 26 to 37 days in 5 cases, and 44 to 56 days in the remaining 5 cases. The results are shown in Table IV.

\section{TABLE IV}

Antibodies for influensa $A$ (PR8) in serums obtained after January 15, 1944 from persons giving a characteristic history of clinical influenza during the epidemic (Dec. 1943 and early in Jan. 1944)

\begin{tabular}{|c|c|c|c|c|c|}
\hline \multirow{2}{*}{$\begin{array}{l}\text { Case } \\
\text { no. }\end{array}$} & \multirow{2}{*}{$\begin{array}{l}\text { Date of } \\
\text { onset }\end{array}$} & \multirow{2}{*}{$\begin{array}{l}\text { Date of } \\
\text { serum }\end{array}$} & \multirow{2}{*}{$\begin{array}{l}\text { Days } \\
\text { after } \\
\text { onset }\end{array}$} & \multicolumn{2}{|c|}{ Titer v8. PR8 } \\
\hline & & & & C.F. & A.I. \\
\hline 14 & Dec. 1 & Jan. 22 & 52 & 16 & 8 \\
\hline 15 & Dec. 5 & Jan. 22 & 48 & 128 & 64 \\
\hline 16 & Dec. 5 & Jan. 24 & 50 & 128 & 64 \\
\hline 17 & Dec. 11 & Jan. 24 & 44 & $<16$ & $<4$ \\
\hline 18 & Dec. 15 & $\begin{array}{l}\text { Feb. } 9 * \\
\text { Feb. } 16\end{array}$ & $\begin{array}{l}56 \\
63\end{array}$ & $\begin{array}{l}16 \\
64\end{array}$ & $\begin{array}{r}<4 \\
64\end{array}$ \\
\hline 19 & Dec. 18 & Jan. 24 & 37 & 128 & 64 \\
\hline 20 & Dec. 24 & Jan. 22 & 29 & 64 & 32 \\
\hline 21 & Dec. 26 & Jan. 21 & 26 & 128 & 64 \\
\hline 22 & Dec. 27 & Jan. 22 & 26 & 64 & 32 \\
\hline 23 & Dec. 28 & $\begin{array}{l}\text { Jan. } 28 \\
\text { Jan. } 31 \\
\text { Feb. } 10\end{array}$ & $\begin{array}{l}31 \\
34 \\
44\end{array}$ & $\begin{array}{l}512 \\
128 \\
128\end{array}$ & $\begin{array}{l}128 \\
256\end{array}$ \\
\hline 24 & Jan. 4 & Jan. 24 & 20 & 64 & 16 \\
\hline 25 & Jan. 4 & Jan. 17 & 13 & 128 & 64 \\
\hline 26 & Jan. 10 & $\begin{array}{l}\text { Jan. } 21 \\
\text { Jan. } 29 \\
\text { Feb. } 1\end{array}$ & $\begin{array}{l}11 \\
19 \\
22\end{array}$ & $\begin{array}{r}128 \\
64 \\
128\end{array}$ & $\begin{array}{l}64 \\
64 \\
64\end{array}$ \\
\hline
\end{tabular}

* The patient was admitted on this date for a recurrence of symptoms similar to those of her earlier attack of influenza in December.

In 3 cases, the titer of complement fixation with PR8 was 16 or less. In each of these cases, the serum was obtained more than 6 weeks following the onset of influenza. In 1 of them, Case 18, the patient was admitted on February 9 for a recurrence of symptoms similar to those of her original attack of influenza on December
15. A second serum obtained 1 week later showed a titer of 64 , suggesting either a response to the second infection or an anamnestic reaction. In 9 of the other 10 cases, the titers were 64 or 128.

In Case 23, the titer of the first serum obtained 1 month after the influenzal infection was 512 and 2 subsequent samples each had a titer of 128 . It is of interest that this patient entered the hospital for a Staphylococcus aureus septicemia and probably had endocarditis but the original focus could not be determined. The portal of entry may well have been the respiratory tract and the original staphylococcal infection, though symptomless, may have been related to the earlier influenzal infection.

The results of the agglutination-inhibition tests with PR8 roughly paralleled those of the complement fixation tests as in the previous cases. Most of the titers, however, showed a 2-fold difference in favor of the latter test.

These findings suggest that, following a widespread epidemic of influenza $A$, significant titers of antibodies against the epidemic type can be demonstrated in most persons who give a history of having had symptoms of influenza during the epidemic. The antibodies in the present cases were demonstrable for as long as 6 to 8 weeks after the onset of symptoms in many instances.

\section{ANTIBODIES FOR INFLUENZA A IN CASES OF BAC- \\ TERIAL PNEUMONIA HAVING A HISTORY OF CLINICAL INFLUENZA DURING THE EPIDEMIC}

Sera were obtained from 24 patients who were in the hospital for severe pneumonia during and after the epidemic of influenza. These patients all gave a history of having symptoms of influenza during the epidemic. The results of the serological tests and some of the relevant data in these cases are summarized in Table $\mathrm{V}$.

The onset of the symptoms of influenza in these cases occurred between November 24 and January 7 and the pneumonia began between December 4 and March 1 . The interval between the onset of the 2 diseases varied. In 11 cases, the pneumonia began at about the same time or within 5 days after the influenza; in 7 others, the interval was 7 to 16 days; while in the remaining 6 cases, the onset of the pneumonia 
TABLE V

Antibodies for influensa $A$ (PR8) in cases of secere bacterial pneumonia occurring during and after the epidemic in patients with characteristic history of clinical influensa during the epidemic

\begin{tabular}{|c|c|c|c|c|c|c|c|c|c|}
\hline \multirow{2}{*}{$\begin{array}{l}\text { Case } \\
\text { no. }\end{array}$} & \multirow{2}{*}{$\begin{array}{l}\text { Date of onset } \\
\text { of influenza }\end{array}$} & \multirow{2}{*}{$\begin{array}{l}\text { Date of } \\
\text { serum }\end{array}$} & \multirow{2}{*}{$\begin{array}{c}\text { Days after } \\
\text { onset of } \\
\text { influenza }\end{array}$} & \multicolumn{2}{|c|}{ Titer vs. PR8 } & \multicolumn{4}{|c|}{ Relevant facts concerning the pneumonia } \\
\hline & & & & C.F. & A.I. & Onset & $\begin{array}{l}\text { Days after } \\
\text { influenza }\end{array}$ & Organism & w.B.c. \\
\hline 27 & Nov. 24 & Jan. 18 & 55 & 512 & 512 & Dec. 31 & 37 & S. au. & $6.5-10.0$ \\
\hline 28 & Nov. 30 & Dec. 11 & 11 & 128 & 64 & Dec. $4 \ddagger$ & 4 & Pn. 1(t) & $4.5-20.6$ \\
\hline 29 & Dec. 1 & Jan. 18 & 49 & 256 & 128 & Jan. 1 & 31 & Str. $\alpha$. & $5.2-5.4$ \\
\hline 30 & Dec. 11 & Jan. 17 & 37 & 512 & 512 & Dec. 11 & $\mathbf{0}$ & Pn. 23* & $10.0-11.4$ \\
\hline 31 & Dec. 12 & Jan. 18 & 37 & 256 & 512 & Jan. 12 & 31 & Str. $\alpha$ & $9.3-10.3$ \\
\hline 32 & Dec. 12 & Dec. 22 & 10 & 256 & 256 & Dec. 15 & 3 & Pn. 17 & $2.7-5.4$ \\
\hline 33 & Dec. 15 & Feb. 9 & 56 & 128 & 128 & Jan. 25 & 41 & Pn. 8 & $15-22$ \\
\hline 34 & Dec. 18 & Jan. 17 & 31 & 256 & 64 & Dec. 25 & 7 & Neg. & 22 \\
\hline 35 & Dec. 18 & Jan. 18 & 31 & 256 & 64 & Jan. 1 & 13 & Str. $\alpha$ & $6.0-13.2$ \\
\hline 36 & Dec. 19 & $\begin{array}{ll}\text { Jan. } & 11 \\
\text { Jan. } & 17\end{array}$ & $\begin{array}{l}23 \\
29\end{array}$ & $\begin{array}{l}128 \\
128\end{array}$ & $\begin{array}{r}128 \\
64\end{array}$ & Dec. 19 & 0 & Pn. 25(t) & $4.5-15.0$ \\
\hline 37 & Dec. 20 & $\begin{array}{l}\text { Dec. } 29 \\
\text { Jan. } 11 \\
\text { Jan. } 17 \\
\text { Feb. } 9\end{array}$ & $\begin{array}{r}9 \\
22 \\
28 \\
51\end{array}$ & $\begin{array}{r}64 \\
128 \\
128 \\
64\end{array}$ & $\begin{array}{r}64 \\
128 \\
128 \\
64\end{array}$ & Dec. 25 & 5 & S. au. $(+)$ & $5.6-14.9$ \\
\hline 38 & Dec. 20 & Jan. 18 & 29 & 512 & 1024 & Dec. 28 & 8 & S. au.* & $12-14$ \\
\hline 39 & Dec. 20 & Jan. 17 & 28 & 128 & 128 & Jan. 13 & 24 & Pn. 23 & 16 \\
\hline 40 & Dec. 21 & $\begin{array}{ll}\text { Jan. } 11 \\
\text { Jan. } 18\end{array}$ & $\begin{array}{l}21 \\
28\end{array}$ & $\begin{array}{l}1024 \\
1024\end{array}$ & $\begin{array}{l}1024 \\
1024\end{array}$ & Dec. 22 & 1 & $\begin{array}{l}\text { S. au. } \\
\text { Pn. } 3\end{array}$ & $8.2-25$ \\
\hline 41 & Dec. 23 & Jan. 17 & 25 & 512 & 256 & Dec. 30 & 7 & S. au. & $4.1-7.2$ \\
\hline 42 & Dec. 23 & Jan. 17 & 25 & 32 & 32 & Dec. 26 & 3 & Pn. 7(+) & $6.4-15.4$ \\
\hline 43 & Dec. 25 & Jan. 17 & 23 & 64 & 64 & Jan. 10 & 16 & Pn. 2(+) & $4.0-7.5$ \\
\hline 44 & Dec. 25 & Jan. 18 & 24 & 128 & 64 & Dec. 28 & 3 & Pn. 1 & $9.2-28$ \\
\hline 45 & Dec. 27 & Jan. 17 & 21 & 64 & 64 & Jan. 10 & 14 & Pn. 25 & $\begin{array}{ll}19 & -24\end{array}$ \\
\hline 46 & Dec. 27 & Jan. 18 & 22 & 128 & 64 & Dec. 28 & 1 & Pn. $7(+)$ & $5.6-11.5$ \\
\hline 47 & Jan. 2 & Jan. 18 & 16 & 128 & 64 & Jan. 4 & 2 & Pn. 3(+) & $5.6-14$ \\
\hline 48 & Jan. 2 & $\begin{array}{ll}\text { Jan. } & 15 \\
\text { Jan. } & 18\end{array}$ & $\begin{array}{l}13 \\
16\end{array}$ & $\begin{array}{l}64 \\
64\end{array}$ & $\begin{array}{l}64 \\
32\end{array}$ & Jan. 10 & 8 & S. au. & 15 \\
\hline 49 & Jan. 3 & Mar. 7 & 64 & 32 & 32 & Mar. 1 & 58 & Str. $\alpha$ & $8.0-10$ \\
\hline 50 & Jan. 7 & Jan. 18 & 11 & 64 & 64 & Jan. 8 & 1 & Str. $\alpha$ & $6.4-12.6$ \\
\hline
\end{tabular}

$\ddagger$ Died Dec. 11. Virus isolation from the lung attempted but failed.

$(+)$ Same organism obtained from blood culture.

* Sputum positive for tubercle bacilli in convalescence.

The months Nov. and Dec. are in 1943, Jan. to Mar. are 1944

C.F. = complement fixation; A.I. = inhibition of hen's red cell agglutination (Hirst).

S. au. = Staphylococcus aureus (hemolytic and coagulase positive).

Str. $\alpha=$ Alpha hemolytic streptococcus; Pn. = pneumococcus (Number represents the type).

W.B.C. = Range of total white blood count during the febrile period (Thousands). 
occurred from 24 to 58 days after the first symptom of influenza.

The predominant organism obtained during the pneumonia was a pneumococcus in 12 of the cases, Staphylococcus aureus in 5 cases, and both a pneumococcus and staphylococcus in 1 case. Positive blood cultures were obtained in 6 of the pneumococcal pneumonias and in 1 of the staphylococcal pneumonias. In 5 cases, the predominant organism was an alpha hemolytic streptococcus and no significant pathogen was recovered from 1 case. In these last 6 cases, the signs and symptoms did not differ materially from those of the other cases. All of them, however, had received sulfonamide therapy before the materials were obtained for culture and this may have accounted for the failure to obtain more significant pathogens which may have been present earlier and accounted for the pulmonary lesions.

Of interest was the finding of leukopenia or of low normal leukocyte counts in most of these cases during the height of the febrile stage of the pneumonia. Leukocyte counts below 5000 were obtained in 5 cases, between 5000 and 6500 in 8, and between 7800 and 10,000 in 4 cases. Polynuclear neutrophiles with many immature forms predominated in all these cases. Higher counts were noted later in the course of the acute illness in some of the cases.

Single specimens of serum were obtained in most of these cases during the third week in January while a few were obtained at other times. In 4 cases, additional sera were obtained after a few days. The interval between the onset of the influenza and the time the serum was obtained varied from 9 to 64 days and was more than 31 days in 6 cases.

The titers of influenza $A$ antibodies in these cases were comparable to those obtained during convalescence in the influenza cases studied during the epidemic. They were generally higher than those obtained in the cases with a history of influenza but without pneumonia. The intervals between the influenza and the serum collections were somewhat longer in the latter group of cases, but this probably did not account for the difference, since some of the later sera in the pneumonia cases showed somewhat higher titers.
A titer of 32 was obtained by the complement fixation and agglutination-inhibition tests in 2 cases. In one of them, the serum was obtained on the 64th day after the influenza, and in the other, it was obtained on the twenty-fifth day after the influenza and early in the course of a severe bacteremic pneumonia. Of the remaining cases, the sera of 12 had titers of 64 or 128 by the complement fixation test and 10 had titers of 256 or higher. The agglutination-inhibition titers were were very similar to those obtained by the complement fixation tests. The differences in titers of the same sera by the 2 tests were similar to those obtained in the 2 previous groups of cases. Most of the titers were the same or showed a 2 -fold difference and only an occasional serum showed a 4-fold difference in titer with the 2 tests.

The serological findings in these cases thus corroborated the clinical histories. They indicate that these patients with severe pneumonia, many of whom responded less favorably than usual to intensive sulfonamide therapy, had had recent infections with influenza A. They suggest further that the influenzal infection may have been a factor not only in the pathogenesis of these pneumonias but also in their severity.

\section{INFLUENZAL ANTIBODIES IN PERSONS WITHOUT A HISTORY OF CLINICAL INFLUENZA}

In the latter half of January when most of the sera from the latter group of pneumonia patients were obtained, a search was also made for other patients with severe pneumonia who denied having had, during the epidemic, symptoms which could be interpreted as those of influenza. Very few such cases were found on the wards at the time but some were encountered subsequently. Sera were obtained from a few such cases and from a number of others without pneumonia. These served, in a way, as controls for the previous 2 groups of cases and supplied further data concerning the significance of the antibody titers in relation to the history of influenza which was obtained. The hospital patients and personnel from whom the sera were obtained fell into 2 groups; one included those from whom a history was elicited of a recent simple upper respiratory tract infection consisting mostly of coryza and cough without 
constitutional symptoms, or of acute follicular tonsillitis; the other group consisted of persons who denied any symptoms of respiratory tract infections since the outbreak of the epidemic.

INFLUENZAL ANTIBODIES AFTER SIMPLE UPPER RESPIRATORY TRACT INFECTIONS

Sera were obtained on one or more occasions from 15 persons who gave a history of having had, between November 15 and February 12, symptoms of upper respiratory tract infection without the constitutional symptoms of influenza. Included were 5 patients with pneumococcal pneumonia of whom 3 had positive blood cultures and 1 died. In 1 additional case, alpha hemolytic streptococcus was obtained in cultures of the sputum during a typical attack of lobar pneumonia although its etiological rôle is doubtful. Among the others were 3 hospital staff members, 1 of whom had had follicular tonsillitis, and 6 patients who were in the hospital for a variety of conditions, including another case of acute hemolytic streptococcal tonsillitis. Virus isolation was attempted in the latter case and was unsuccessful.

No significant titers or rises in titer of antibodies for influenza $A$ were found in any of these sera. A complement fixation titer of 32 was obtained in 6 cases including 2 in which a previous serum had a titer of 16 . The titers in the rest of the cases were 16 or less. Comparable results were obtained with the Hirst inhibition test. As in the previous cases, the titers by the 2 tests in the individual sera were in close agreement.

\section{RESULTS IN PERSONS WITHOUT PREVIOUS UPPER RESPIRATORY TRACT INFECTION}

Sera of 26 persons who denied having any symptoms of acute upper respiratory tract infections during the previous 3 months were also tested. Most of these sera were obtained between January 6 and 24. Included were sera from 4 patients with severe pneumonia and from several members of the hospital and laboratory staff. The maximum complement fixation titer was 128 in 2 instances and 64 in 2 others, and, in each of these 4 cases, the agglutinationinhibition titer was 64 . The titers in all the remaining cases were 32 or less by either test.
Here again, the titers in the individual sera obtained by the complement fixation and agglutination-inhibition tests were in essential agreement. In Case 80, an 8-fold rise in titer to 64 was noted between December 6 and January 17 although no symptoms of infection had occurred in the intervening period. This person handled all of the virus-infected materials that were brought in from the wards for this present study and carried out all of the influenza virus isolations. None of those who studied the patients on the wards and obtained the materials for the isolations had any significant titers or rises in titer. Three of the cases of influenza, however, were in hospital interns.

\section{INFLUENZAL ANTIBODIES IN POST-EPIDEMIC} CASES OF INFLUENZA

A few of the sera in the last 2 groups were obtained in February and early in March. At first, it was felt that the epidemic had subsided early in January, since typical cases of influenza were not being encountered after that time. On February 1, however, evidence was obtained that influenza might still be occurring sporadically. On that day, a patient (Case A-2) died after only a few hours in the hospital and, at autopsy, showed an acute hemorrhagic bronchopneumonia from which no significant pathogen could be obtained. Influenza virus, however, was readily isolated from a filtrate of this lung. Subsequently, several other cases of clinical influenza were admitted to the hospital and strains of influenza virus were isolated from 6 clinical cases, and from the lung of another fatal case, in which the symptoms of influenza began between January 23 and March 11.

The symptoms in most of these cases were quite characteristic of influenza but the subsequent course in 3 of them was atypical. The histories of these 3 cases will, therefore, be presented briefly.

Case 66. The patient was a 45-year-old cook who was admitted to the hospital on February 7. He had been in very good health until 1 week previously when he had slight coryza without constitutional symptoms. On February 6 , he suddenly developed severe headache, generalized aches and pains in his bones and muscles, and frequent chills followed by fever. There was slight cough and yellowish mucoid sputum. The admission temperature was $102^{\circ} \mathrm{F}$., pulse 70 , and respiration 25 . Except 
for a few râles in the left lower chest, physical examination was essentially negative. The leukocyte count was $\mathbf{4 7 0 0}$ on that day and 7800 the next day and there was a predominance of mature polymorphonuclear neutrophiles. On symptomatic therapy the patient's temperature dropped gradually to normal in about 36 hours, but 24 hours later, the temperature again rose and thereafter assumed a swinging character, ranging from 99 to 101 or $102^{\circ}$ daily, with pulse remaining below 80, until February 25. Except for headaches and general aches in his legs, there were no symptoms accompanying the fever. The cough subsided after the first day. An x-ray of the chest taken on admission showed slight clouding of the left lower lobe but 3 subsequent films, including 1 taken on February 9 , showed the lungs to be normal. No cause for the continued fever could be determined. Throat washings were taken for virus isolations a few hours after entry. All bacteriological studies were negative for pathogenic organisms in the sputum, stools, and urine, and serological studies for enteric agglutinins, cold hemagglutinins, and heterophile antibodies were all negative.

Case $A-2$. A 39-year-old Italian iron worker was admitted to the hospital on January 31 complaining of breathlessness, cough, and bloody sputum. He was well until January 23 when he had a slight "head cold" and then began to feel worn out and depressed with general malaise, anorexia, apathy, and a feeling of fullness in the head. This continued until January 26 when he had several shaking chills in rapid succession and these were followed by fever and cough. Two days later the cough increased and became productive of bloody sputum which he continued to raise until the time of admission to the hospital. At that time, the temperature was $98.4^{\circ} \mathrm{F}$., pulse 100 , respirations 28 , and blood pressure $138 / 88$. The patient was extremely dyspneic, cyanotic, and breathing with audible tracheal râles. He was raising copious amounts of sputum containing dark red blood. There was diffuse dulness of both lungs and loud bubbling râles were heard. X-ray showed diffusely scattered nodular consolidation throughout both lung fields. The white blood count was 19,000 with 88 per cent polymorphonuclear neutrophiles. The patient died within a few hours. Autopsy showed a diffuse hemorrhagic bronchopneumonia which is described elsewhere (1). Some of the lung was used for virus isolation.

Case $A-3$. A 61-year-old painter was admitted in a moribund condition on March 6 and died a few hours later. From his relatives it was learned that he had felt unusually tired during the preceding 2 months. 'One week before entry, he had symptoms which might be interpreted as those of clinical influenza. This, however, did not keep him from work. On March 4, while at work, he had a severe shaking chill and, by the time he reached home, he felt markedly feverish and prostrated. On the next day, he had chilly sensations, pain in the right lower chest which was severe and pleuritic in character, and cough productive of large amounts of dark rusty sputum. These symptoms increased in severity.

On arriving at the hospital, the patient's temperature was $103^{\circ} \mathrm{F}$., pulse 136 , respirations 42 , and blood pressure
158/78. He was markedly dyspneic and cyanotic, coughing and raising rusty sputum, grunting with obvious pleuritic pain. There were signs of frank consolidation of the right lower lobe and diffuse moist râles throughout the rest of the lung. The leukocyte count was 2000 of which 60 per cent were polymorphonuclear neutrophiles, most of them immature. The sputum was loaded with type I pneumococci in pure culture, both by direct Neufeld test and by direct culture, and the same organism was cultured from the blood. In spite of oxygen, intravenous sulfonamides, antipneumococcic serum, and penicillin, the patient failed to register improvement and died 10 hours after entry. Autopsy showed lobar pneumonia of the right lower lobe, seropurulent effusion of the right pleura, and a hemorrhagic congestion of the rest of the lung. Some of this hemorrhagic lung was used for virus isolation. Type I pneumococcus was obtained from cultures of the heart's blood, all lobes of the lungs, and the pleural fluid. Details of the pathology are given elsewhere (1).

The results of the attempts to isolate virus in these 8 cases are summarized in the lower part of Table I and the bacteriological findings are listed on the right hand side of Table II. The viruses were isolated with about the same ease as in the epidemic cases. They were obtained from unfiltered and filtered materials, both in mice and in chick embryos. In Case 70, however, one attempt with unfiltered material and another with the filtered washings in eggs were abandoned as failures. The former was contaminated with hemolytic streptococci and caused early deaths of the embryos. Virus was obtained from the same unfiltered washings in mice.

The viruses isolated from the fatal cases gave typical serological reactions of influenza $A$ when tested with immune rabbit serums. All the others gave atypical reactions although none of them reacted to a higher titer with anti-B than with anti-A serum. A study of these strains and their relationship to typical strains of $A$ and $B$ virus as well as to the epidemic strains, is now in progress.

In Table VI are shown the results of tests for influenzal antibodies in these 8 cases and in 3 other cases of clinical influenza which were observed at the same time but in which virus isolations were not attempted. The poor antibody response in this group of cases is in sharp contrast to the definite and sharp increase in influenza $A$ antibodies in the epidemic cases shown in Table III. In only 1 case in the present group was there a 4-fold rise in titer against the homologous virus and none showed 
TABLE VI

Influenzal antibodies in clinical cases of influenza occurring between January 23 and March 11, 1944

\begin{tabular}{|c|c|c|c|c|c|c|c|c|c|}
\hline \multirow{3}{*}{ Case no. } & \multirow{3}{*}{ Date of onset } & \multirow{3}{*}{ Date of serum } & \multirow{3}{*}{$\begin{array}{l}\text { Days } \\
\text { after } \\
\text { onset }\end{array}$} & \multicolumn{6}{|c|}{ Titers of influenzal antibodies } \\
\hline & & & & \multicolumn{2}{|c|}{ PR8(A) } & \multicolumn{2}{|c|}{ Lee(B) } & \multicolumn{2}{|c|}{ Homologous } \\
\hline & & & & C.F. & A.I. & C.F. & A.I. & C.F. & A.I. \\
\hline 66 & Feb. 5 & $\begin{array}{l}\text { Feb. } 8 \\
\text { Feb. } 16 \\
\text { Feb. } 28 \\
\text { Apr. } 12\end{array}$ & $\begin{array}{r}2 \\
10 \\
22 \\
66\end{array}$ & $\begin{array}{r}<8 \\
<8 \\
8 \\
<8\end{array}$ & $\begin{array}{l}16 \\
32 \\
16 \\
16\end{array}$ & $\begin{array}{l}<4 \\
<4 \\
<4 \\
<4\end{array}$ & $\begin{array}{l}8 \\
4 \\
4 \\
8\end{array}$ & $\begin{array}{l}8 \\
8 \\
8 \\
8\end{array}$ & $\begin{array}{l}128 \\
128 \\
128 \\
128\end{array}$ \\
\hline 67 & Feb. 7 & $\begin{array}{l}\text { Feb. } 11 \\
\text { Feb. } 17 \\
\text { Mar. } 2 \\
\text { Mar. } 22\end{array}$ & $\begin{array}{r}4 \\
10 \\
24 \\
44\end{array}$ & $\begin{array}{l}32 \\
32 \\
32 \\
32\end{array}$ & $\begin{array}{l}16 \\
16 \\
16 \\
16\end{array}$ & & $\begin{array}{l}8 \\
8 \\
8 \\
4\end{array}$ & $\begin{array}{l}<8 \\
<8 \\
<8 \\
<8\end{array}$ & $\begin{array}{r}<4 \\
<4 \\
4 \\
8\end{array}$ \\
\hline 68 & Feb. 26 & $\begin{array}{l}\text { Feb. } 29 \\
\text { Mar. } 7 \\
\text { Mar. } 14 \\
\text { Mar. } 21 \\
\text { Apr. } 12\end{array}$ & $\begin{array}{r}3 \\
10 \\
17 \\
24 \\
46\end{array}$ & $\begin{array}{l}8 \\
8 \\
8 \\
8 \\
8\end{array}$ & $\begin{array}{r}64 \\
128 \\
128 \\
128 \\
128\end{array}$ & $\begin{array}{l}32 \\
32 \\
32 \\
32 \\
32\end{array}$ & $\begin{array}{l}32 \\
32 \\
32 \\
32 \\
32\end{array}$ & $\begin{array}{l}16 \\
16 \\
16 \\
32 \\
16\end{array}$ & $\begin{array}{l}64 \\
64 \\
64 \\
64 \\
64\end{array}$ \\
\hline 69 & Mar. 5 & $\begin{array}{l}\text { Mar. } 12 \\
\text { Mar. } 18 \\
\text { Mar. } 28\end{array}$ & $\begin{array}{r}7 \\
13 \\
23\end{array}$ & $\begin{array}{l}<8 \\
<8 \\
<8\end{array}$ & $\begin{array}{l}16 \\
32 \\
32\end{array}$ & $\begin{array}{l}<4 \\
<4 \\
<4\end{array}$ & $\begin{array}{r}16 \\
16 \\
8\end{array}$ & $\begin{array}{l}<8 \\
<8 \\
<8\end{array}$ & $\begin{array}{r}8 \\
16 \\
16\end{array}$ \\
\hline 70 & Mar. 6 & $\begin{array}{l}\text { Mar. } 8 \\
\text { Mar. } 20 \\
\text { Apr. } 12\end{array}$ & $\begin{array}{r}2 \\
14 \\
37\end{array}$ & $\begin{array}{r}<8 \\
<8 \\
8\end{array}$ & $\begin{array}{l}32 \\
32 \\
32\end{array}$ & $\begin{array}{l}<4 \\
<4 \\
<4\end{array}$ & $\begin{array}{l}8 \\
8 \\
8\end{array}$ & $\begin{array}{l}<8 \\
<8 \\
<8\end{array}$ & $\begin{array}{l}16 \\
16 \\
16\end{array}$ \\
\hline 71 & Mar. 11 & $\begin{array}{l}\text { Mar. } 12 \\
\text { Mar. } 27\end{array}$ & $\begin{array}{r}1 \\
16\end{array}$ & $\begin{array}{l}<8 \\
<8\end{array}$ & $\begin{array}{l}16 \\
16\end{array}$ & $\begin{array}{l}8 \\
8\end{array}$ & $\begin{array}{l}8 \\
8\end{array}$ & $\begin{array}{l}<8 \\
<8\end{array}$ & $\begin{array}{r}8 \\
16\end{array}$ \\
\hline 72 & Jan. 24 & $\begin{array}{l}\text { Jan. } 31 \\
\text { Feb. } 7\end{array}$ & $\begin{array}{r}7 \\
14\end{array}$ & $\begin{array}{l}8 \\
8\end{array}$ & $\begin{array}{l}<4 \\
<4\end{array}$ & & $\begin{array}{l}<4 \\
<4\end{array}$ & & \\
\hline 73 & Jan. 27 & $\begin{array}{l}\text { Feb. } 8 \\
\text { Feb. } 15 \\
\text { Feb. } 23 \\
\text { Mar. } 7\end{array}$ & $\begin{array}{l}12 \\
19 \\
27 \\
40\end{array}$ & $\begin{array}{r}<16 \\
16 \\
16 \\
16\end{array}$ & $\begin{array}{l}4 \\
4 \\
8 \\
8\end{array}$ & & $\begin{array}{l}16 \\
16 \\
16 \\
32\end{array}$ & . & \\
\hline 74 & Feb. 23 & $\begin{array}{l}\text { Mar. } 1 \\
\text { Mar. } 8\end{array}$ & $\begin{array}{r}7 \\
14\end{array}$ & $\begin{array}{l}8 \\
8\end{array}$ & $\begin{array}{l}64 \\
64\end{array}$ & & $\begin{array}{l}4 \\
4\end{array}$ & & \\
\hline A2 & Jan. 23 & Feb. 1 & 9 & 16 & 8 & & 4 & & 4 \\
\hline A3 & Mar. 4 & Mar. 6 & $2(?)$ & 64 & 64 & & 256 & & 256 \\
\hline
\end{tabular}

Note: In Cases 67, 73, A2, and A3, the C.F. tests with PR8 were done 3 to 4 months before the corresponding A.I. tests. In all other instances, the 2 tests were done on the same sera, simultaneously. In Case 74, there was Pn. 9 pneumonia, onset Feb. 28. In Cases A2 and A3, viruses were isolated from the lungs at autopsy. The sera in these 2 cases were obtained on the day of death.

more than a 2-fold rise in titer of PR8 antibodies. Furthermore, a titer of 64 or higher with any of the viruses was obtained in only 4 cases, including 1 that was fatal. The others showed no significant titers or rises in titer with their own, the PR8, or the Lee strains.

\section{RESULTS OF TESTS FOR INFLUENZA B ANTIBODIES}

Tests for influenza $B$ antibodies were done by the agglutination-inhibition method in almost all of the sera. All of the acute and convalescent sera from the epidemic and post-epidemic cases were included. The Lee strain of influenza $B$ was used in these tests. The results are summarized in Table VII according to the various groups of cases. Maximum titers of 64 or higher were obtained in only 5 cases, as follows:

Case 21. (Table IV) Influenza began December 26. Serum of January 21 tested with PR8 showed titers of 128 and 64 by complement fixation and agglutination- 
TABLE VII

Results of Hirst inhibition tests with the Lee strain of influenza $B$ in 6 groups of cases

\begin{tabular}{r|r|r|r|r|r|r|r|r}
\hline \hline & \multirow{6}{*}{$\begin{array}{c}\text { Listed in } \\
\text { table }\end{array}$} & \multicolumn{5}{|c|}{ Maximum titer } & Total \\
\cline { 3 - 7 } & & $<8$ & 8 & 16 & 32 & 64 & 128 & \\
\hline I & III & 2 & 1 & 6 & 4 & & & 13 \\
II & IV & 3 & 2 & 3 & 3 & 1 & & 12 \\
III & V & 2 & 5 & 10 & 4 & & & 21 \\
IV & $\# \#$ & 2 & 3 & 6 & 3 & 1 & & 15 \\
V & $\#$ & 1 & 8 & 10 & 5 & 1 & 1 & 26 \\
VI & VII & 3 & 4 & 1 & 2 & & $1^{*}$ & 11 \\
\hline Total & & 13 & 23 & 36 & 21 & 3 & 2 & 98 \\
\hline
\end{tabular}

* Titer 256.

* These tables omitted to conserve space. Group IV includes the persons who gave a history of simple respiratory infections and Group V includes those who denied having any upper respiratory tract infections.

inhibition, respectively. The inhibition titer with the Lee strain was 64 .

Case 51. Common cold (?) began December 26 and pneumococcus type 7 pneumonia began January 29 and was. complicated by pneumococcal endocarditis. The sera of February 19 and 28 had titers of 64 and 32, respectively, of inhibition with the Lee strain. The titer against PR8 in both sera was 16.

Cases 85 and 97 . The titers with the Lee strain in sera of January 22 and February 9, were 64 and 128, respectively. The former was from a case of peptic ulcer and the latter from a case of lung abscess. Both had titers of 16 or less against PR8. There was no history of recent upper respiratory tract infection in either case.

Case $A-3$. (Table VI) In this case, the serum taken shortly before the patient died had a titer of 64 when tested with PR8 and with the homologous strain isolated from the lung. The titer against the Lee strain was 256 .

In none of these cases was a significant rise in titer demonstrated. In Case 11, however, there was a 4-fold rise during convalescence from an original level of 8 . This was one of the epidemic cases and the same sera showed a rise in titer against PR8 from 16 to 256 by the complement fixation test and from 32 to 128 by the inhibition test.

It is apparent, therefore, that significant titers of influenza $B$ antibodies were uncommon and some of the few that were encountered were associated with high titers of influenza $A$ antibodies. Significant rises in titer to influenza $B$ alone were not demonstrated in any case. Indeed, the marked rises in titers against influenza $A$ were accompanied by a slight rise in titer against the B strain in only 1 case.

\section{DISCUSSION}

The comparative ease with which isolation of virus was accomplished, both in the clinical cases and from the autopsy material during and after the height of the epidemic, is worthy of note. Two methods were used which in this laboratory have proved the simplest and most successful. The first is the intranasal inoculation of white mice and serial passage of lung suspensions. The second is the intra-allantoic inoculation of chick embryos followed by similar passage of the allantoic fluid. Both filtered and unfiltered materials were used in the first instance and yielded similar results. Filtration of lung suspensions or allantoic fluid was frequently necessary before subsequent passages when bacterial contaminants were encountered but these did not usually affect the virus content materially. In some of the later attempts, the initial inoculations of infected throat washings, sputum, or lung suspensions were immediately preceded by the injection of 2.5 to $5.0 \mathrm{mgm}$. of sodium sulfadiazine and 250 units of penicillin contained in $0.1 \mathrm{ml}$. of distilled water, intra-abdominally in mice and into the allantoic sac of the chick embryos. This permitted successful isolations from heavily infected materials such as sputum and lungs from cases of pneumonia. Similar results in this epidemic have been obtained with throat washings in chick embryos (16).

At first it was felt that it was essential to obtain materials for virus isolation during the first 2 days of illness and the 4 epidemic cases were so chosen. In later cases, however, isolations were accomplished from washings obtained on the third to the seventh day. This was considered possible after virus had been isolated from the lung in Case A-2, in which death occurred on the ninth day after the onset of the influenza. In a previous sporadic case, influenza A virus was isolated from the lungs of a patient who died on the seventh day (1). In the present study, the determining factor in the choice of clinical cases for virus isolation was that the patients were still acutely ill with typical symptoms of influenza and had a temperature of $102^{\circ} \mathrm{F}$. or higher at the time when the material was collected. On the whole, the patients from whom viruses were isolated represented cases of 
more than average severity and a large proportion of them had pulmonary complications.

Isolations of influenza A from the lungs of cases dying of staphylococcal pneumonia complicating influenza have been previously reported in one case (17) and in 3 cases (18). Presumptive evidence of the presence of influenza $A$ virus was obtained (3) from the lung in a case of mixed staphylococcal and streptococcal pneumonia which occurred at the Boston City Hospital during the 1940-41 epidemic (19). During March and April 1943, influenza A virus was isolated from the lungs of 2 sporadic cases as already mentioned. One of them was a case of staphylococcal pneumonia, and no significant bacterial pathogen was obtained from the second case $(1,2)$. During the present study, influenza virus was isolated from the lungs in 3 fatal cases of pneumonia, one infected with Staphylococcus aureus and beta hemolytic streptococci, a second with type I pneumococcus, and a third in which no definite pathogen was found and only a few alpha hemolytic streptococci were obtained in cultures of the sputum and the lung.

The identity of most of the viruses isolated from cases during the height of the epidemic was readily established as influenza $A$ both by neutralization tests in mice and by agglutinationinhibition tests with influenza A (PR8) and B (Lee) antisera. The reactions of these viruses closely resembled that of PR8 except those from Case 4 and Case A-1 which reacted to a considerable, though lesser degree with the influenza $B$ antiserum. The antibody response of the epidemic cases was, on the whole, quite characteristic of infection with a strain resembling PR8. In the 4 clinical cases from which virus was isolated, furthermore, the antibody response to PR8 in each instance closely paralleled that obtained against the homologous strain of virus. These findings, though not very extensive, suggest that the agent responsible for most of the cases during the height of the epidemic, at least the severe ones among them, was an influenza $A$ virus resembling PR8.

In the post-epidemic cases, on the other hand, both the viruses isolated and the antibody responses observed were quite different. Sharp increases in antibody titers against PR8 were not encountered. Indeed, only minor rises in titer, or none at all, were demonstrated, even against the homologous viruses. Some of the latter, although they reacted with PR8 antiserum in moderate or high titer, also reacted with the type $B$ (Lee) antiserum to the same degree or only slightly less. Wide antigenic differences among strains of influenza $A$ have also been noted by several investigators (20 to 22) and among strains of influenza B by another (23). In the present study, the fact that the atypical viruses and antibody responses were obtained, for the most part, some time after the height of the epidemic, suggests the possibility that the antigenic properties of the epidemic strain may have been modified, either by repeated passage in non-susceptible individuals or by prolonged residence in the hosts before manifest infection took place. Alternatively, it could be assumed that these viruses were merely latent ones which the patients were harboring as carriers and which had no relation either to their disease or to the epidemic, but this explanation seems less likely in view of the characteristic symptoms in these cases. The antigenic properties of both groups of viruses and their relationship to each other and to other influenza viruses is now under investigation in collaboration with Dr. John F. Enders and Miss Elizabeth G. Mills.

The isolation of influenza viruses from the lungs of fatal cases of bacterial pneumonia serves also to emphasize the significance of the finding of influenzal antibodies in high titers in other severe cases of pneumonia, observed during and after the height of the epidemic. Similar though less definite findings were reported (3) in the serum of cases of pneumococcal and staphylococcal pneumonia occurring at this hospital during the influenza epidemic of 1940-41. The possible relation of the influenza $A$ virus to the pulmonary infections was suggested at that time and this suggestion is fully supported by the present findings. As in the previous epidemic (24), an unusual number of cases of Staphylococcus aureus pneumonia again occurred as complications of the influenza and some of them were fulminating in character. The rarity with which hemolytic streptococcal complications occurred in the last 2 epidemics is in sharp contrast to their well-known prevalence in the pandemic of 1918. 
High antibody titers for influenza A were obtained in the patients with pneumonia and in the other persons who gave a history of the symptoms of influenza during the epidemic. These are in sharp contrast to the low titers observed at the same time in persons who had symptoms of a common cold or of tonsillitis and in those who denied having had any symptoms of upper respiratory tract infection during the epidemic. This stands out clearly in the summary of the maximum titers of influenza A antibodies which were obtained in the different groups of cases, as shown in Table VIII. To be sure, there were individual instances of high titers among the persons without influenza and of comparatively low titers in some of those who had symptoms of the disease, but these were few. The contrast between these groups of cases appears to be significant and the combinations of the high titers and the symptoms probably represents the result of influenzal virus infection during the epidemic. The findings also suggest that other simple respiratory infections may occur during an epidemic of influenza and many of them probably can be differentiated from the influenza cases both clinically and by their failure to elicit the proper antibody response. It is of interest that antibody titers in the post-epidemic cases of influenza when viewed as a group in this perspective, correspond more closely to those found in the non-influenza groups of cases, again emphasizing the atypical character of these post-epidemic cases.

It has been noted, in connection with each of the groups of cases, that the titers of PR8 antibodies obtained in the individual serums by both the complement fixation and by the agglutination-inhibition tests were in close agreement. Most of the differences that were noted indicated a 2-fold higher titer with the former. These findings are in essential agreement with those of another worker (20) when account is taken of the different 'methods of expressing the titers used by this author for the 2 tests. In reviewing the present data, and after repeating a number of the tests, it became evident that most of the large discrepancies could be accounted for by the deterioration of the influenzal antibodies in the sera on storage at refrigerator temperatures (5 to $10^{\circ} \mathrm{C}$.), and, in addition, contamination may have accounted for some of them. Except in some of the post-epidemic cases listed in Table VIII, the complement fixation titers were all carried out within 2 months of the time when the sera were collected. The agglutinationinhibition titers were done from 3 to 5 months later. The validity of the complement fixation titers is attested by the fact that a simultaneous control serum preserved at $-72^{\circ} \mathrm{C}$. retained its high titer throughout and a number of the sera showed the same titers when retested within the first 2 months.

A number of the sera were later retested with the same preparation of PR8 virus and both tests run simultaneously. This time most of the sera showed lower complement fixing titers than in the tests done 5 months previously and many of them gave 8- or even 16-fold titers by the agglutination-inhibition test. In a few sera, however, the titers were the same with both tests. The titers of agglutination-inhibition obtained in the later tests of these sera were

TABLE VIII

Maximum titers of antibodies for influenza $A$ (PR8) in 6 groups of cases

\begin{tabular}{|c|c|c|c|c|c|c|c|c|c|c|c|c|c|c|c|c|c|c|c|}
\hline \multirow{2}{*}{ Group* } & \multicolumn{10}{|c|}{ Complement fixation } & \multicolumn{9}{|c|}{ Agglutination-Inhibition } \\
\hline & $<16$ & 16 & 32 & 64 & 128 & 256 & 512 & 1024 & 2048 & Total & $<16$ & 16 & 32 & 64 & 128 & 256 & 512 & 1024 & Total \\
\hline $\begin{array}{c}\text { I } \\
\text { III } \\
\text { IV } \\
\text { V } \\
\text { VI }\end{array}$ & $\begin{array}{r}1 \\
6 \\
11 \\
7\end{array}$ & $\begin{array}{l}1 \\
3 \\
3 \\
2\end{array}$ & $\begin{array}{l}1 \\
2 \\
6 \\
7 \\
1\end{array}$ & $\begin{array}{l}1 \\
4 \\
4 \\
2 \\
1\end{array}$ & $\begin{array}{l}2 \\
6 \\
8 \\
2\end{array}$ & $\begin{array}{l}3 \\
5\end{array}$ & $\begin{array}{l}2 \\
1 \\
4\end{array}$ & $\begin{array}{l}2 \\
1\end{array}$ & 2 & $\begin{array}{l}13 \\
13 \\
24 \\
15 \\
25 \\
11\end{array}$ & $\begin{array}{r}2 \\
6 \\
15 \\
3\end{array}$ & $\begin{array}{l}1 \\
7 \\
4 \\
2\end{array}$ & $\begin{array}{l}2 \\
2 \\
2 \\
3 \\
3\end{array}$ & $\begin{array}{r}2 \\
7 \\
10 \\
\\
4 \\
2\end{array}$ & $\begin{array}{l}2 \\
5 \\
1\end{array}$ & $\begin{array}{l}5 \\
1 \\
2\end{array}$ & $\begin{array}{l}4 \\
3\end{array}$ & 2 & $\begin{array}{l}13 \\
13 \\
24 \\
15 \\
26 \\
11\end{array}$ \\
\hline Total & 25 & 9 & 17 & 12 & 18 & 8 & 7 & 3 & 2 & 101 & 26 & 14 & 12 & 25 & 8 & 8 & 7 & 2 & 102 \\
\hline
\end{tabular}

* See Table 7 . 
essentially the same as those found at the time of the previous tests which were done 1 to 2 months previously. Discrepancies, however, were noted occasionally with this test when different preparations of virus were used as previously observed by others (25):

From these observations, it was inferred that the antibody titers probably had deteriorated on storage, and, in a few instances, because of contaminations. The findings also suggested that the rate at which the deterioration took place varied markedly in the individual sera. Possibly also, the 2 antibodies deteriorated in some sera at different rates, but this aspect requires further study. The absolute values shown for the agglutination-inhibition titers may, therefore, not represent the actual titers originally present in those sera. This, however, does not detract from the value of the observations made since most of the inhibition tests were carried out within a brief period. Furthermore, the results of these tests corresponded quite closely with those obtained by the complement fixation tests which were carried out some time previously. The findings, however, suggest that for the most reliable results and comparisons, tests for influenzal antibodies should be carried out within a short time after the sera are collected. Special care is probably required for the preservation of the sera in order to avoid deterioration of these antibodies.

\section{SUMMARY AND CONCLUSIONS}

Influenza viruses were isolated early in the course of the disease from throat washings and also from the lungs of fatal cases of pneumonia, both during and after the height of the epidemic of influenza which occurred in Boston in December 1943 and early in January 1944. Successful isolations were made from filtered and unfiltered materials, both by the intranasal inoculation of mice and by allantoic inoculations in chick embryos.

The reactions of the viruses obtained during the height of the epidemic and the antibody response to characteristic infections occurring at that time indicated that the epidemic cases were caused chiefly by strains of influenza A similar to PR8.
The post-epidemic cases were atypical, not only with respect to the viruses which were isolated from some of them but particularly in their antibody responses, both to their own strains and to the standard PR8 strain.

No definite evidence of infection with influenza B was obtained in any of the cases studied, either during or after the epidemic.

In the sera of persons who gave a characteristic history of influenza during the epidemic, significant titers of antibodies to the PR8 strain of influenza A were demonstrated for as long as 12 weeks after the onset of these symptoms. Such significant titers were not demonstrated during the same period in cases of pneumonia nor in other persons who either denied having any symptoms of acute respiratory infection or had symptoms which could be recognized as those of the common cold and not influenza.

These findings suggest that characteristic clinical histories and serological findings obtained as long as $\mathbf{2}$ or $\mathbf{3}$ months after a definite epidemic of clinical influenza may serve to differentiate most, but not all of those who, during the height of the epidemic, were infected with influenza virus from those who had other types of respiratory infections. The same does not hold true for acute respiratory infections which occur after the epidemic has subsided.

Of particular interest were the high titers of antibodies to PR8 that were demonstrated in severe cases of bacterial pneumonia which occurred during and shortly after the epidemic and in which there was a recent history of clinical influenza. These findings and the isolation of influenza virus from the lungs in 3 fatal cases suggest that the occurrence and severity of the pneumonia in such cases is related to the antecedent infections with the influenza virus.

The most frequent organisms obtained in the pneumonias which followed influenza were pneumococci of various types and Staphylococcus aureus. No significant bacterial pathogen could be recognized in some of the pneumonia cases, including a fatal one in which a virus was recovered from the lung. Both Staphylococcus aureus and hemolytic streptococcus were obtained from one of the other fatal cases and type 1 pneumococcus was cultured from the third. 
Comparable results were obtained in this study with the complement fixation and agglutination-inhibition tests.

Evidence was also obtained that influenzal antibodies may deteriorate after a few months in sera stored at 5 to $10^{\circ} \mathrm{C}$.

\section{BIBLIOGRAPHY}

1. Parker, F., Jr., Joliffe, L. S., Barnes, M. W., and Finland, M., Pathology of pneumonia complicating influenza. In preparation.

2. Finland, M., Parker, F., Jr., Barnes, M. W., and Joliffe, L. S., Acute myocarditis in influenza A infections. Am. J. M. Sc., In press.

3. Pearson, H. E., Eppinger, E. C., Dingle, J. H., and Enders, J. F., A study of influenza in Boston during the winter of 1940-1941. New England J. Med., 1941, 225, 763.

4. Lennette, E. H., Rickard, E. R., Hirst, G. K., and Horsfall, F. L., Jr., The diverse etiology of epidemic influenza. Pub. Health Rep., 1941, 56, 1777.

5. Prevalence of communicable diseases in the United States. Pub. Health Rep., 1944, 59, 79.

6. Anonymous. The influenza epidemic. Lancet, 1944, $1,137$.

7. Francis, T., Jr., Transmission of influenza by a filterable virus. Science, 1934, 80, 457.

8. Francis, T., Jr., A new type of virus from epidemic influenza. Science, 1940, 92, 405.

9. Hirst, G. K., The agglutination of red cells by allantoic fluid of chick embryos infected with influenza virus. Science, 1941, 94, 22.

10. Hirst, G. K., Adsorption of influenza hemagglutinins and virus by red blood cells. J. Exper. Med., 1942, 76, 195.

11. Francis, T., Jr., and Salk, J. E., A simplified procedure for the concentration and purification of influenza virus. Science, 1942, 96, 499.

12. Hirst, G. K., Direct isolation of human influenza virus in chick embryos. J. Immunol., 1942, 45, 293.

13. Hirst, G. K., The quantitative determination of influenza virus and antibodies by means of red cell agglutination. J. Exper. Med., 1942, 75, 49.'

14. Eaton, M. D., and Rickard, E. R., Application of the complement-fixation test to the study of epidemic influenza. Am. J. Hyg., 1941, 33, 23.

15. Samper, B. A., and Finland, M., Present day treatment of the pneumonias. M. Clin. North America, 1944 , p. 1067.

16. Thigpen, M., and Crowley, J., Isolation of influenza A by intra-allantoic inoculation of untreated throat washings. Science, 1943, 98, 516.

17. Stokes, J., Jr., and Wolman, I. J., The probable synergism of human influenza virus and Staphylococcus aureus in a rapidly fatal respiratory infection. Internat. Clin., 1940, 1, 115.

18. Stuart-Harris, C. H., Andrewes, C. H., Smith, W., Chalmers, D. K. M., Cowen, E. G. H., and Hughes, D. L., A Study of Epidemic Influenza: with Special Reference to the 1936-7 Epidemic. Medical Research Council, Special Report Series, No. 228. His Majesty's Stationery Office, London, 1938.

19. Wollenman, O. J., Jr., and Finland, M., Pathology of staphylococcal pneumonia complicating clinical influenza. Am. J. Path., 1943, 19, 23.

20. Friedewald, W. F., Qualitative differences in the antigenic composition of influenza $A$ virus strains. J. Exper. Med., 1944, 79, 633.

21. Hirst, G. K., Studies of antigenic differences among strains of influenza A by means of red cell agglutination. J. Exper. Med., 1943, 78, 407.

22. Magill, T. P., and Sugg, J. Y., The significance of antigenic differences among strains of the "A group" of influenza viruses. J. Exper. Med., 1944, 80, 1.

23. Gordon, I., Demonstration of antigenic differences between different strains of influenza B. J. Immunol., 1942, 44, 231.

24. Finland, M., Peterson, O. L., and Strauss, E., Staphylococcic pneumonia occurring during an epidemic of influenza. Arch. Int. Med., 1942, 70, 183.

25. Stuart-Harris, C. H., Observations on the agglutination of fowl red cells by influenza viruses. Brit. J. Exper. Path., 1943, 24, 33. 